Canadian Journal of Fisheries and Aquatic Sciences, 1992, v.49, n.7, pp.1466-1473.

Online ISSN: 1205-7533

Print ISSN: 0706-652X

DOI:10.1139/f92-161

http://pubs.nrc-cnrc.gc.ca/rp-ps/journalDetail.jsp?jcode=cjfas\&lang=eng

http://article.pubs.nrc-

cnrc.gc.ca/RPAS/rpv?hm=HInit\&journal=cjfas\&volume=49\&calyLang=eng\&afpf=f92-161.pdf (C) 1992 NRC Canada 


\title{
Planktivores and Plankton Dynamics: Effects of Fish Biomass and Planktivore Type
}

\author{
Xavier Lazzaro' \\ Aquatic Ecology Laboratory, Department of Zoology, The Ohio State University, Columbus, OH 43210, USA
}

Ray W. Drenner

Department of Biology, Texas Christian University, Fort Worth, TX76129, USA

Roy A. Stein

Aquatic Ecology Laboratory, Department of Zoology, The Ohio State University, Columbus, OH 43210, USA

and J. Durward Smith

Department of Biology, Texas Christian University, Fort Worth, TX 76129, USA

\begin{abstract}
Lazzaro, X., R. W. Drenner, R. A. Stein, and J. D. Smith. 1992. Planktivores and plankton dynamics: effects of fish biomass and planktivore type. Can. J. Fish. Aquat. Sci. 49: 1466-1473.

We quantified the effects of planktivore biomass and planktivore type in an experimental mesocosm study of factorial design in which five levels of fish biomass $\left(0-75 \mathrm{~g} / \mathrm{m}^{3}\right)$ were cross-classified with two plantivore types: filter-feeding gizzard shad (Dorosoma cepedianum) and visual-feeding bluegill (Lepomis macrochirus). As fish biomass increased, cladocerans, cyclopoids, particulate phosphorus (PP) $>200 \mu \mathrm{m}$, and chironomids declined; conversely, rotifers, primary productivity, chlorophyll a, turbidity, unicellular flagellates, colonial and unicellular green algae, pennate diatoms, total phosphorus, and 20-200 and 12-20 $\mu \mathrm{m}$ PP were enhanced. In the presence of gizzard shad, as compared with bluegill, cyclopoids, turbidity, unicellular green algae, pennate diatoms, $>200 \mu \mathrm{m} \mathrm{PP}$, and chironomid tubes were higher whereas colonial green algae and $<0.2 \mu \mathrm{m}$ PP were lower. Fish biomass operated independently of planktivore type for most variables, except copepods, colonial green algae, turbidity, and 20-200 $\mu \mathrm{m}$ PP. Although gizzard shad and bluegill have different trophic cascade pathways, fish biomass was more important than planktivore type as a regulator of plankton communities and water quality.

Les auteurs ont quantifié les incidences de la biomasse et du type de planctophage dans le cadre d'une étude expérimentale en mésocosmes. Cette étude était conçue en fonction d'un plan factoriel d'expérience combinant cinq niveaux de biomasse de poisson (de 0 à $75 \mathrm{~g} / \mathrm{m}^{3}$ ) avec deux types de planctophage, soit l'alose à gésier (Dorosoma cepedianum), un filtreur, et le crapet arlequin (Lepomis macrochirus), un chasseur visuel. Une augmentation de la biomasse de poisson était accompagnée d'une baisse du nombre de cladocères, de cyclopoïdes et de chironomides et de la teneur en phosphore particulaire (PP) $>200 \mu \mathrm{m}$; inversement, l'abondance de rotifères, de flagellés unicellulaires, d'algues vertes coloniales et unicellulaires, de diatomées pennées, la productivité primaire, la turbidité et les teneurs en chlorophylle a, en phosphore total et en PP de 20 à $200 \mu \mathrm{m}$ et de 12 à $20 \mu \mathrm{m}$ ont augmenté. En présence de l'alose à gésier, l'abondance de diatomées pennées, de cyclopoïdes, d'algues vertes unicellulaires et de tubes de chironomides, la turbidité et la teneur en PP $>200 \mu \mathrm{m}$ étaient plus élevées que lorsque le crapet arlequin était présent; par contre, l'abondance d'algues vertes coloniales et la teneur en PP $<0,2 \mu \mathrm{m}$ étaient moins élevées. L'influence de la biomasse de poisson était indépendante du type de planctophage pour la plupart des variables, sauf en ce qui concerne les copépodes, les algues vertes coloniales, la turbidité et le PP de 20 à $200 \mu \mathrm{m}$. Bien que la chaîne des cascades trophiques de l'alose à gésier et celle du crapet soleil soient différentes, la biomasse de poisson jouait un rôle plus important que le type de planctophage comme régulateur des communautés planctoniques et de la qualité de l'eau.
\end{abstract}

Received February 20, 1991

Accepted January 13, 1992

Reçu le 20 février 1991

(JA906) Accepté le 13 janvier 1992

$\mathbf{P}$

lanktivorous fish regulate phytoplankton and water quality of lakes through their consumption of plankton and alteration of nutrient cycles (Lazzaro 1987; Vanni 1987a; Northcote 1988). How planktivorous fish influence plankton

\footnotetext{
'Present address: ORSTOM, The French Institute of Scientific Research for Development through Cooperation, Laboratory of Tropical Hydrobiology and Oceanography (HOT), 911, Avenue Agropolis, BP 5045, 34032 Montpellier, France.
}

and water quality depends on fish biomass (McQueen et al. 1986; Threlkeld 1988; Drenner and Smith 1991). Empirically derived regressions demonstrate negative relationships between planktivore biomass and zooplankton biomass as well as between zooplankton biomass and phytoplankton biomass (Vijverberg and van Densen 1984; McQueen and Post 1985; McQueen et al. 1986). These functional relationships between planktivore biomass and plankton biomass appear to be nonlin- 
ear (Drenner et al. 1987; Threlkeld 1988; Drenner and Smith 1991).

Although differences in the biomass-related effects of the two types of planktivores, filter feeders and visual feeders, on plankton and water quality are unknown, studies (Drenner et al. 1986; Lazzaro 1987) suggest that these two planktivore types have different trophic cascade pathways. Visual feeders locate and attack single zooplankton prey (Janssen 1976) whereas filter feeders do not visually detect individual prey, but strain prey and particles from engulfed water using gill rakers or other entrapment structures (Mummert and Drenner 1986; Drenner et al. 1987). Visual feeders directly suppress populations of large zooplankters, and may indirectly enhance populations of phytoplankton and small and or highly evasive zooplankton (Hambright et al. 1986). In contrast, pump filter feeders directly suppress populations of cladocerans and large phytoplankton, and indirectly enhance copepods and small algae (Kajak et al. 1977; Drenner et al. 1986, 1987).

To quantify how fish biomass and planktivore type affect plankton dynamics and water quality, and to determine whether the effects of fish biomass and planktivore type operate independently, we performed an experiment of factorial design in which five levels of fish biomass were cross-classified with two planktivore types. We used filter-feeding gizzard shad (Dorosoma cepedianum) and visual-feeding bluegill (Lepomis macrochirus), either of which can dominate the fish biomass of lakes and reservoirs in the central and southeastern United States (Jenkins 1967; Cooper et al. 1971). Gizzard shad (>40 mm standard length (SL)) an omnivorous pump filterfeeding clupeid, feeds on phytoplankton, zooplankton, and detritus (Mummert and Drenner 1986) whereas bluegill, a carnivorous centrarchid, feeds primarily on zooplankton and benthos (Werner 1977).

\section{Material and Methods}

We conducted this experiment in 20 white fiberglass tanks at the outdoor mesocosm facility at Texas Christian University. Tanks were $1.8 \mathrm{~m}$ in diameter, $2.2 \mathrm{~m}$ high, and contained about $5500 \mathrm{~L}$. Tanks were continuously mixed with an airlift mixer system to prevent stratification (Drenner et al. 1986).

Because we were searching for generality and used the tanks as model systems, we did not try to synchronize conditions in tanks with those from any one lake or reservoir. We filled the tanks with water from a small $(0.7 \mathrm{ha})$, shallow pond $(2.5 \mathrm{~m}$ maximum depth) with bluegill and western mosquitofish ( $\mathrm{Gam}$ busia affinis), but no piscivores. The zooplankton of the pond was dominated by small cyclopoid copepods and rotifers, with few cladocerans (R. W. Drenner, pers. obs.). Water was pumped into the tanks on 6 April 1989 using a gasolinepowered diaphragm pump. To stimulate the development of cladoceran populations, we added about 800 cladocerans (Simocephalus and Daphnia, mainly D. pulex) to each tank. These cladocerans were obtained from two holding tanks filled 1 mo before the experiment. Because sand is used by gizzard shad to break algal cells during digestion $(\mathbf{R}$. W. Drenner, pers. obs.), 3.8 $\mathrm{L}$ of autoclaved brick sand was added to each tank on 10-11 April.

Beginning 16 April, $518 \mu \mathrm{g} \mathrm{N} / \mathrm{L}$ as $\mathrm{NH}_{4} \mathrm{Cl}$ and $32 \mu \mathrm{g} / \mathrm{L}$ as $\mathrm{H}_{3} \mathrm{PO}_{4}$ (concentrations after adding to tanks) were added to each tank every other day. Based on previous experience (Drenner et al. 1989), adding $\mathrm{N}$ and $\mathrm{P}$ at these concentrations would help maintain a total nitrogen to total phosphorus (TN:TP) ratio similar to that of the source pond.

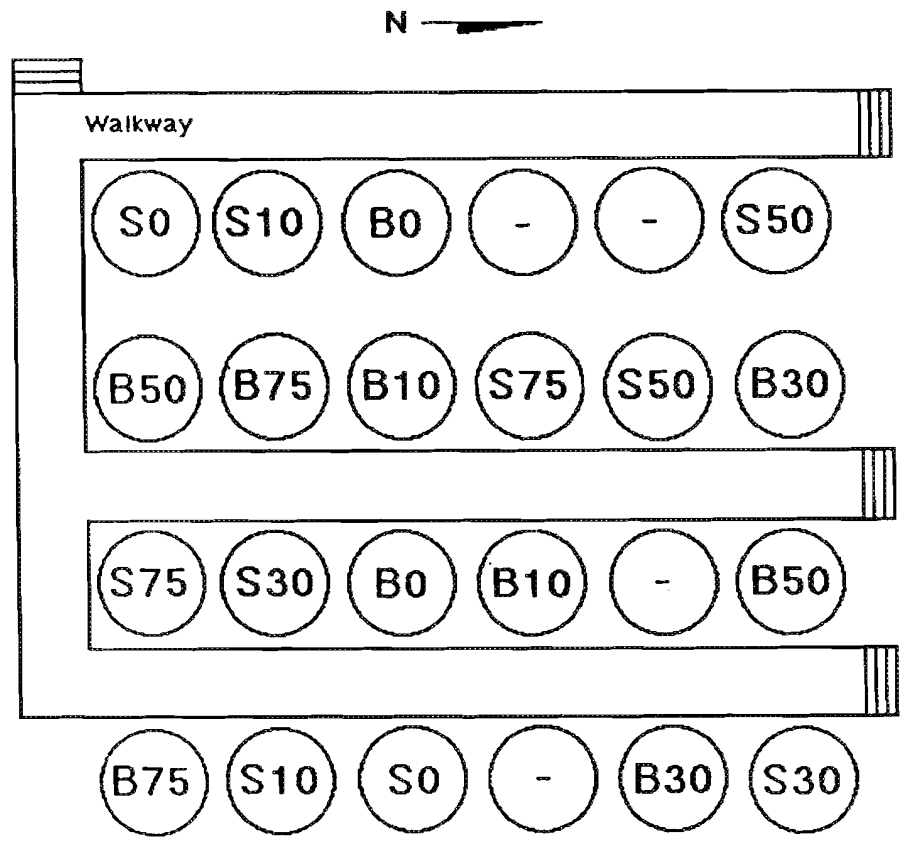

FIG. 1. Layout of the experimental tanks and sampling walkway. Assigned treatment combinations are indicated by the letters S (gizzard shad) and $B$ (bluegill) for planktivore type followed by numbers indicating stocked fish biomass $\left(0,10,30,50\right.$, and $75 \mathrm{~g} / \mathrm{m}^{3}$, wet mass).

On 7 April, bluegill and gizzard shad were electrofished from the pond and Interlocken Lake, Arlington, Texas, respectively, transported, and acclimated in holding tanks. On 15 April, fish were netted from these holding tanks, weighed in plastic bags (nearest $0.1 \mathrm{~g}$ ), and stocked into experimental tanks according to the following design. Five levels of fish biomass $(0,10,30$, 50 , and $75 \mathrm{~g} / \mathrm{m}^{3}$, wet mass) were cross-classified with two levels of planktivore type (gizzard shad and bluegill) resulting in 10 treatment combinations. Each treatment combination was randomly assigned to tanks and replicated twice (Fig. 1). The two replicates of the no-fish treatment combination for gizzard shad (S0) were distinct from those for bluegill (B0). The five biomass levels were composed of $0,1,3,5$, and 7 gizzard shad and $0,3,9,15$, and 21 bluegill per tank. Mean individual weights ( $\pm 1 \mathrm{SD})$ and length ranges of stocked gizzard shad and bluegill were $53.8 \pm 10.1 \mathrm{~g}(130-160 \mathrm{~mm} \mathrm{SL})$ and $17.2 \pm 9.5 \mathrm{~g}(50-100 \mathrm{~mm} \mathrm{SL})$, respectively. Mean standing crops of gizzard shad ( $>200 \mathrm{~kg} / \mathrm{ha}$ ) (Schoonover and Thompson 1954; Aggus et al. 1979; Drenner et al. 1982; Hill 1983; Ali and Bayne 1987; Kirk and Davies 1987) are typically higher than those of bluegill ( $<200 \mathrm{~kg} / \mathrm{ha}$ ) (Carlander 1977; Aggus et al. 1979; Hill 1983; Hambright et al. 1986; Kirk and Davies 1987). We selected the maximum stocking biomass of $75 \mathrm{~g} / \mathrm{m}^{3}$ (about $1570 \mathrm{~kg} / \mathrm{ha}$ ) to ensure that gizzard shad were stocked across biomass gradients found in natural lake and reservoirs. Maximum gizzard shad biomass can be as high as $1236 \mathrm{~kg} / \mathrm{ha}$ (Schoonover and Thompson 1954). To complete the factorial design, bluegill were stocked at similar biomass levels as gizzard shad even though maximum biomass reported for bluegill is $750 \mathrm{~kg} / \mathrm{ha} \mathrm{(Carlander} \mathrm{1977).} \mathrm{Therefore,} \mathrm{biomass}$ levels of 50 and $75 \mathrm{~g} / \mathrm{m}^{3}$ (about 1000 and $1500 \mathrm{~kg} / \mathrm{ha}$, respectively) were unrealistically high for bluegill.

Beginning 13 April (day 0), tanks were sampled at weekly intervals for $4 \mathrm{wk}$. Temperature was measured daily with a YSI model $43 \mathrm{TD}$ tele-thermometer and ranged from 12 to $25^{\circ} \mathrm{C}$. Zooplankton were sampled with vertical tows of a $63-\mu \mathrm{m}$-mesh, 12-cm-diameter Wisconsin plankton net. Triplicate tows were 
taken from each tank on each date, combined, preserved in 5\% sucrose-formalin, and counted under a dissecting microscope. Densities were not corrected for net efficiency.

Integrated water column samples for analysis of turbidity, chlorophyll $a$, phytoplankton, total nitrogen (TN), total phosphorus (TP), and size fractions of particulate phosphorus (PP) were collected with a PVC tube lowered to near the tank botom and then closed with a valve on the lower end of the tube. Turbidity was measured weekly with a Hach turbidimeter. Chlorophyll $a$ samples on all dates were filtered through Millipore HAWP membrane filters $(0.45-\mu \mathrm{m}$ pore size), wrapped in aluminum foil, and frozen. Chlorophyll $a$ was extracted in a $2: 1$ chloroform-methanol solution in the dark at $20-22^{\circ} \mathrm{C}$ for at least $4 \mathrm{~h}$ and absorbance measured at $665 \mathrm{~nm}$ (Wood 1985). Phytoplankton samples were preserved with $1.0 \%$ Lugol's iodine and settled overnight in sedimentation chambers. Seven to 10 random fields were counted (algae identified to genus) with an inverted microscope at $200 \times$; algal densities were computed per taxonomic group. Phytoplankton sizes were determined by measuring 10 individuals per taxon using an ocular micrometer. Particles $<2 \mu \mathrm{m}$ were not counted.

Samples for TN were digested with alkaline potassium persulfate (D'Elia et al. 1977) and absorbance was measured at $220 \mathrm{~nm}$ (APHA 1985). Samples for TP were digested with potassium persulfate (Menzel and Corwin 1965) and analyzed using a modification of the malachite green method (Van Veldhoven and Mannaerts 1987) in which $1 \mathrm{~mL}$ of color reagent was added to $5-\mathrm{mL}$ subsamples of the $20-\mathrm{mL}$ total digestions and absorbance measured at $610 \mathrm{~nm}$.

On days 0,14 , and 28, PP concentrations were determined for five size fractions: $>200 \mu \mathrm{m}$ (macroplankton), $20-200 \mu \mathrm{m}$ (microplankton), 12-20 $\mu \mathrm{m}$ (large nanoplankton), 3-12 $\mu \mathrm{m}$ (small nanoplankton), and $0.2-3 \mu \mathrm{m}$ (picoplankton) (Mazumder et al. 1988). Samples were fractionated within $1 \mathrm{~h}$ of collection with $47-\mathrm{mm}$ Nuclepore polycarbonate filters with pore sizes of $0.2,3$, and $12 \mu \mathrm{m}(50,100$, and $300 \mathrm{~mL}$ filtered, respectively) and prewashed $47-\mathrm{mm}$ Nitex screens with mesh sizes of 20 and $200 \mu \mathrm{m}$ ( $3 \mathrm{~L}$ filtered). After filtration (vacuum pressure $<50 \mathrm{~mm} \mathrm{Hg}, 1 \mathrm{~mm} \mathrm{Hg}=133.322 \mathrm{~Pa}$ ), each filter was placed into a screw-capped test tube containing $35 \mathrm{~mL}$ of distilled and deionized water. Phosphorus concentrations in the fractionated samples were determined after oxidation with potassium persulfate with the same methodology used for TP. Filtrates $(35 \mathrm{~mL})$ passing through filters with a pore size of $0.2 \mu \mathrm{m}$ were stored at $4^{\circ} \mathrm{C}$ and analyzed without the oxidation step. Because filtrates through $0.2-\mu \mathrm{m}$ filters may actually contain viruses and ultramicrobacteria $(0.02-0.2 \mu \mathrm{m})$, as well as phototrophic pico- and nanoplankton $(0.2-2.0 \mu \mathrm{m})$, the phosphorus size fraction $<0.2 \mu \mathrm{m}$ may contain not only orthophosphate $\left(\mathrm{PO}_{4}-\mathrm{P}\right)$ but some PP also (Stockner et al. 1990).

On days 1,15 , and 29 , phytoplankton primary productivity was determined by in situ carbon fixation $\left({ }^{14} \mathrm{C}\right.$ method) with two $250-\mathrm{mL}$ light bottles and one $250-\mathrm{mL}$ dark bottle (to correct for bacterial photosynthesis; Parkin and Brock 1980) incubated at $1 \mathrm{~m}$ in each tank from about 11:00 to 15:00. For each tank, an integrated water column sample collected with the PVC tube sampler was mixed in a pitcher and poured into the incubation bottles and then injected with $1 \mathrm{~mL}$ of a $3 \mu \mathrm{Ci} / \mathrm{mL}$ $(111 \mathrm{kBq} / \mathrm{mL})$ solution of $\mathrm{NaH}^{14} \mathrm{CO}_{3}$. Initial dissolved inorganic carbon was calculated from total inflection point alkalinity (Gran 1952; Wetzel and Likens 1979). Immediately after incubations, $50 \mathrm{~mL}$ of each sample (stored in the dark) was filtered, collected on a Millipore HAWP membrane filter (0.45$\mu \mathrm{m}$ pore size), exposed to $1 \mathrm{~N} \mathrm{HCl}$ vapors for $30 \mathrm{~min}$, dried overnight, placed in a dioxane-base fluor, and counted with an automatic liquid scintillation counter.

On 16 and 17 May (days 33 and 34), tanks were drained through a fiberglass screen and fish removed, measured (SL, nearest $1 \mathrm{~mm}$ ), and weighed (nearest $0.1 \mathrm{~g}$ ). No fish died during the experiment. Immediately after tank draining, tubedwelling chironomids and periphyton were sampled. Chironomid tubes were counted within a $1100-\mathrm{cm}^{2}$ rectangular area from the surface to a depth of $30 \mathrm{~cm}$ on one side of each tank. One $4 \times 4 \mathrm{~cm}$ area of periphyton was removed with a razor blade from the center of the chironomid sampling area. Periphyton samples were collected on Millipore HAWP membrane filters $(0.45-\mu \mathrm{m}$ pore size), wrapped in aluminum foil, and frozen. Periphytic chlorophyll $a$ was extracted by the method used for phytoplankton.

All statistical analyses were performed on SYSTAT (Wilkinson 1989). Because fish were stocked on day 2 , data from day 0 were excluded from the analysis. Main effects of fish biomass and planktivore type and their interaction effects (fish biomass $\times$ planktivore type) were analyzed with repeatedmeasures ANOVA, using the Multivariate General Model Hypothesis with grouping factors (five fish biomasses and two planktivore types) and a time trial factor (two sampling dates, days 14 and 28, for primary productivity and PP and four sampling dates, days $7,14,21$, and 28 , for all other variables). Stocked fish biomass, fish growth rate (expressed in wet mass per stocked wet mass per day), periphytic chlorophyll a, and chironomid tube density were analyzed using a two-way ANOVA. Because of low replication and statistical power, we chose a probability level of $\alpha<0.10$ to reduce the chance of making the type II error of failing to reject a false null hypothesis.

\section{Results and Discussion}

Fish biomass significantly affected densities of cladocerans (primarily Daphnia pulex and Chydorus sp.), cyclopoid copepods (primarily Mesocyclops sp. and Acanthocyclops sp., copepodids, and nauplii), and rotifers (primarily Brachionus sp. and Asplanchna sp.). With increasing fish biomass, densities of cladocerans and cyclopoid copepods decreased whereas densities of rotifers were enhanced (Fig. 2). Planktivore type affected cyclopoid densities, which were higher with gizzard shad than with bluegill. The difference in the effects of gizzard shad and bluegill may have occurred because filter-feeding gizzard shad capture cyclopoid copepods with less success than visualfeeding planktivores (Drenner and McComas 1980). However, day-0 cyclopoid densities were higher in tanks that were stocked with gizzard shad than in those that were stocked with bluegill (two-way ANOVA, $P=0.017$ ), complicating our ability to interpret this planktivore type effect.

Fish biomass significantly affected primary productivity, phytoplankton chlorophyll $a$, turbidity, and densities of unicellular flagellates, colonial green algae, unicellular green algae, and pennate diatoms. All these variables increased with increasing fish biomass, except colonial green algae whose density declined at gizzard biomass $>30 \mathrm{~g} / \mathrm{m}^{3}$ (Fig. 2), possibly as a direct consequence of gizzard shad grazing. Planktivore type affected turbidity, unicellular green algae, colonial green algae, and pennate diatoms. All these response variables were higher in the presence of gizzard shad than with bluegill with the exception of colonial green algae.

For most plankton and water quality response variables, fish biomass and planktivore type acted independently, as revealed 



o- o Gizzard Shad

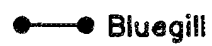

- Pre-Fish Conditions

Fish Biomass $\left(\mathrm{g} / \mathrm{m}^{3}\right)$

FiG. 2. Mean responses of zooplankton, phytoplankton, and water quality variables on four sampling dates (days 7, 14, 21, and 28) after fish introduction and of primary productivity on two sampling dates (days 14 and 28) to fish biomass and planktivore type. Probability values from repeated-measures ANOVA of fish biomass and planktivore type main effects and their interaction effects are indicated from left to right across the type of each graph. $\sqrt{ } \mathrm{MS}$ error is shown in parentheses. Evaluation of fish biomass or planktivore type main effects can be achieved by comparing mean values for treatment combination levels of fish biomass $\left(0,10,30,50\right.$, and $75 \mathrm{~g} / \mathrm{m}^{3}$, wet mass) or those for treatment combinations of planktivore type (gizzard shad versus bluegill), respectively. Interaction effects can be evaluated by nonparallel curves between values of response variables for gizzard shad and values for bluegill across fish biomass levels. Phytoplankton sizes shown are ranges of maximum dimensions. 
by nonsignificant interaction terms $(P>0.10)$. We found significant fish biomass $\times$ planktivore type interactions only for cyclopoid copepods, turbidity, and colonial green algae. To examine these relationships, we computed simple effects to detect differences between gizzard shad and bluegill treatments at each biomass level. At $10 \mathrm{~g} / \mathrm{m}^{3}$, cyclopoid densities were higher with gizzard shad than with bluegill $(P=0.003$; Fig. 2). Turbidity was higher with gizzard shad than with bluegill at biomass $\geqslant 30 \mathrm{~g} / \mathrm{m}^{3}(P<0.01)$. At $75 \mathrm{~g} / \mathrm{m}^{3}$, densities of colonial green algae (primarily Actinastrum spp.) were higher with bluegill than with gizzard shad $(P=0.001)$. At this biomass, bluegill may have indirectly enhanced colonial green algae by suppressing Daphnia because small colonial green algae are particularly vulnerable to grazing by Daphnia (Vanni and Temte 1990) whereas gizzard shad may have directly reduced larger colonial green algae by grazing.

Fish biomass effects on PP were consistent with its effects on zooplankton and phytoplankton. Fish biomass reduced $>200 \mu \mathrm{m}$ PP (macroplankton) and enhanced 20-200 $\mu \mathrm{m}$ PP (microplankton) and 12-20 $\mu \mathrm{m}$ PP (large nanoplankton) (Fig. 3). Bluegill reduced $>200 \mu \mathrm{m}$ PP more dramatically than gizzard shad, most likely due to greater cyclopoid reduction by bluegill compared with gizzard shad. The simultaneous decrease in $>200 \mu \mathrm{m}$ PP and increase in 20-200 $\mu \mathrm{m}$ PP may reflect the shift from copepods and cladocerans to rotifers whereas 12-20 $\mu \mathrm{m}$ PP increased because rotifers cannot graze efficiently $12-20 \mu \mathrm{m}$ particles (Bogdan and Gilbert 1984). The $<0.2 \mu \mathrm{m}$ PP was higher with bluegill than with gizzard shad.

A fish biomass $\times$ planktivore type interaction occurred for 20-200 $\mu \mathrm{m}$ PP. Analysis of simple effects showed that at 30 and $50 \mathrm{~g} / \mathrm{m}^{3}$, concentrations of 20-200 $\mu \mathrm{m}$ PP were higher with gizzard shad than with bluegill $(P=0.008$ and 0.09 , respectively).

Fish biomass and planktivore type did not have significant effects on periphytic chlorophyll $a$ whereas we detected sig- nificant declines in densities of chironomid tubes attached to tank sides with fish biomass. Densities of chironomid tubes were significantly lower with bluegill than with gizzard shad (Fig. 4). Bluegill visually locate and consume benthic prey (Werner 1977). Although gizzard shad of the size used in this study commonly consume sediments and detritus, benthic macroinvertebrates are not included in their diet probably because they do not visually locate individual prey (Mummert and Drenner 1986).

Our results are consistent with other studies suggesting that consumption of macrozooplankton by planktivorous fish results in the enhancement of rotifer densities (Vanni 1987b; Threlkeld 1988) and phytoplankton productivity and biomass (Shapiro et al. 1975; Carpenter et al. 1985, 1987). Suppression of cladocerans and cyclopoids may have permitted rotifers to increase because rotifers are not only outcompeted by $D$. pulex (Gilbert 1985; Vanni 1986), but also may be damaged or killed by the filtering apparatus of cladocerans (Gilbert 1985; Gilbert and Stemberger 1985), or even consumed by Mesocyclops (Williamson and Gilbert 1980). With lower grazing rates and narrower diet breadth (Neil 1984), rotifers permitted phytoplankton to increase.

Gizzard shad consume phytoplankton, but 130-160 mm SL gizzard shad can only efficiently filter particles $>40 \mu \mathrm{m}$ as per interraker distances (Mummert and Drenner 1986; Drenner et al. 1986). Those phytoplankton too small to be grazed by gizzard shad (unicellular flagellates, unicellular green algae, and pennate diatoms $(<20 \mu \mathrm{m}$ in smallest dimension; maximum dimensions are shown on Fig. 2)) came to dominate mesocosms with shad because elongated particles can pass through filters, limited only by their smallest diameter (Runge and Ohman 1982). However, because of their globular shape, larger colonial green algae may have been suppressed by gizzard shad grazing at high biomass.

Fish also influence phytoplankton via alteration of nutrient cycles (Nakashima and Leggett 1980; Vanni 1987a; Threlkeld

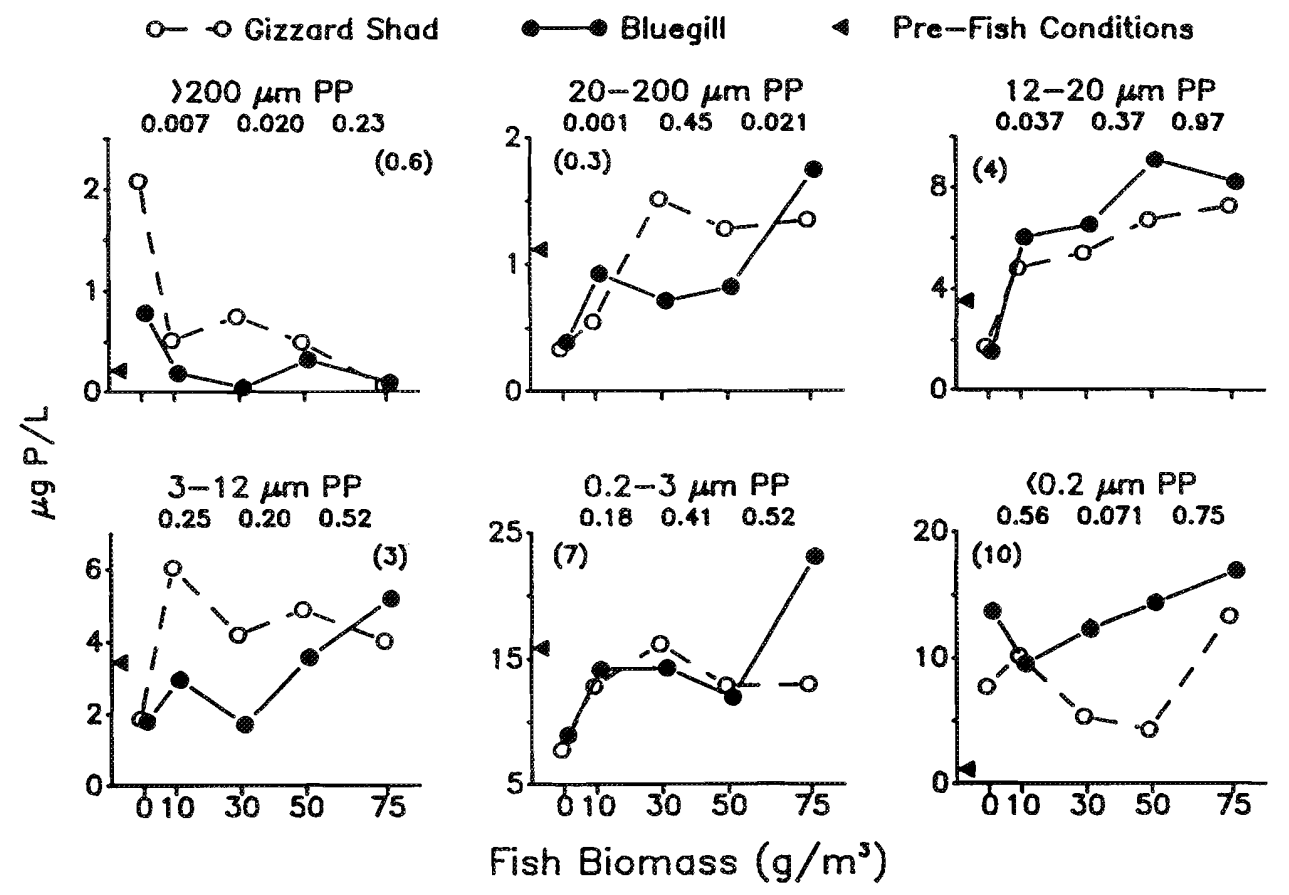

FIG. 3. Mean responses of size fractions of PP on two sampling dates (days 14 and 28) after fish introduction to fish biomass and planktivore type. Probability values from repeated-measures ANOVA, $\sqrt{ } \mathrm{MS}$ error, and evaluation of main and interaction effects, as in Fig. 2. 


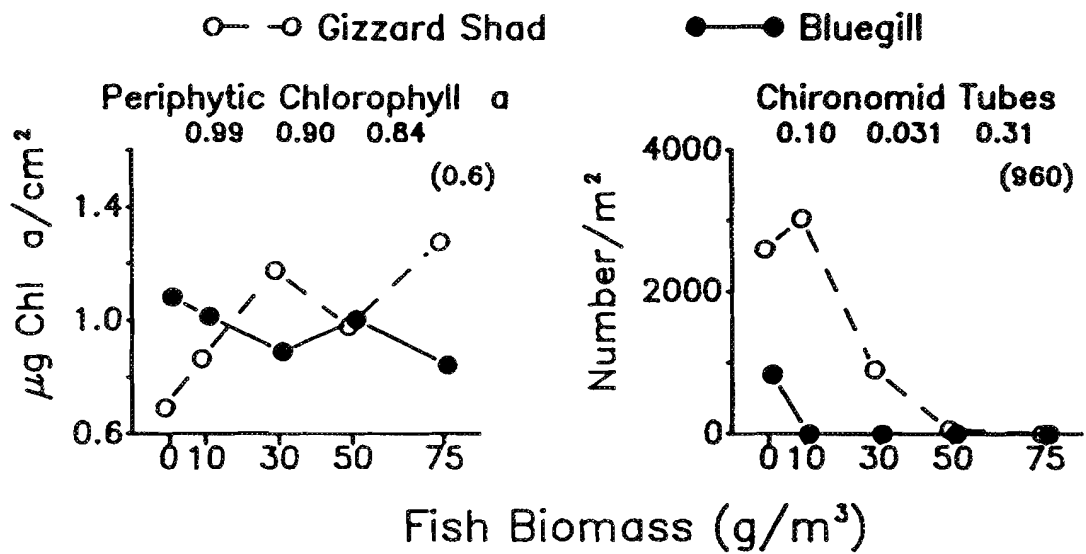

FIG. 4. Mean responses of periphytic chlorophyll $a$ and chironomid tubes density (day 28) to fish biomass and planktivore type. Probability values from two-way ANOVA, $\sqrt{ }$ MS error, and evaluation of main and interaction effects, as in Fig. 2.

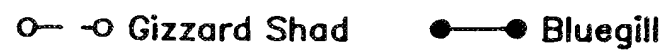

Fish Growth Rate $0.003 \quad 0.001 \quad 0.51$

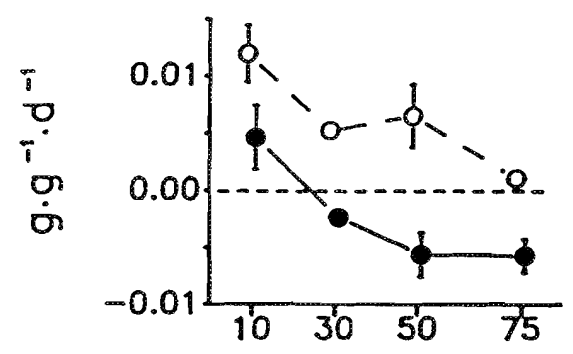

\section{Fish Biomass $\left(\mathrm{g} / \mathrm{m}^{3}\right)$}

FIG. 5. Mean gizzard shad and bluegill growth rates (expressed in wet mass per stocked wet mass per day) across fish biomass levels (two replicates per treatment combination) between stocking and recovering dates (33-34 d). Vertical bars represent \pm 1 SE. Probability values from two-way ANOVA, $\sqrt{ }$ MS error, and evaluation of main and interaction effects, as in Fig. 2.

1988; Northcote 1988). Fish biomass did not influence TN, but TP increased with fish biomass (Fig. 2). Fish have complex effects on nutrient levels, excreting nutrients and altering nutrient cycles through predation (Vanni 1987a; Vanni and Temte 1990; Vanni et al. 1990). Fish can act either as nutrient sources or sinks depending on growth patterns (Threlkeld 1988). In our study, bluegill growth rates were lower than gizzard shad growth rates at all fish biomasses (Fig. 5). Gizzard shad always gained weight, but gizzard shad growth declined with fish biomass. Bluegill growth also declined with fish biomass, but bluegill only gained weight at $10 \mathrm{~g} / \mathrm{m}^{3}$. Phytoplankton enhancement by bluegill may have, in part, resulted from nutrient release caused by loss of bluegill body mass (Threlkeld 1987), but we do not have information about changes in nutrient excretion by bluegill with weight loss to accurately estimate the nutrient loading.

One type of biomanipulation is the reduction of phytoplankton biomass (to increase water transparency) of lakes through reduction of planktivores, permitting herbivorous zooplankton to increase (Shapiro and Wright 1984; Carpenter et al. 1985). A critical question about this biomanipulation technique is whether partial suppression of planktivores by piscivores can improve water quality (McQueen et al. 1986; Shapiro 1990). The answer partially depends on whether the fish biomass phytoplankton biomass relationship is linear or sigmoid. If linear (Carpenter et al. 1985; McQueen et al. 1986), then reductions in planktivores at high biomass will produce improvements in water quality. If sigmoid (Drenner and Smith 1991), then reductions in planktivores at high biomass will not result in commensurate reductions in phytoplankton biomass.

In our study the fish biomass - chlorophyll $a$ relationships were sigmoid. With bluegill, this relationship may be artificial because (1) biomass levels of 50 and $75 \mathrm{~g} / \mathrm{m}^{3}$ are unrealistically high for bluegill in nature (Carlander 1977) and (2) nutrient release resulting from loss of bluegill body mass may have occurred at biomass $>10 \mathrm{~g} / \mathrm{m}^{3}$. In contast, gizzard shad grew at all biomass levels. Carrying capacity for gizzard shad exceeded that for bluegill because shad feed on phytoplankton and detritus in addition to zooplankton (Mummert and Drenner 1986). Our growth rate data are consistent with observations that in lakes and reservoirs, filter-feeding gizzard shad typically maintain higher biomass than visual-feeding bluegill (Carlander 1977; Aggus et al. 1979; Miranda 1983). Phytoplankton biomass increased with gizzard shad biomass in a sigmoid fashion, suggesting that reductions of gizzard shad between 75 and $10 \mathrm{~g} /$ $\mathrm{m}^{3}$ would produce less beneficial effects on chlorophyll than reductions of gizzard shad below $10 \mathrm{~g} / \mathrm{m}^{3}$.

The success of any biomanipulation effort aimed at reducing phytoplankton biomass requires planktivores to be reduced sufficiently to permit zooplankton to increase and or nutrient loading by fish to decrease (Braband et al. 1990), but not so far as to threaten piscivore production (McQueen et al. 1986, 1990). Another type of biomanipulation is the stocking of forage fish to maintain piscivore production. Because water quality improvement and piscivore production enhancement are often contradictory goals, a trade-off between water quality and angler harvest might well be necessary under a biomanipulation program of lake management. Gizzard shad often dominates the forage fish biomass and is the primary prey of most piscivore species (Noble 1981), but it is currently difficult to predict how reductions in gizzard shad biomass (to improve water quality) might affect piscivore production. Partial removals of gizzard shad can have negative, neutral, or even positive effects on piscivore growth; however, most manipulations lacked a reference system and data were not statistically analyzed (DeVries and Stein 1990). Our chlorophyll data (see Fig. 2) suggest that 
gizzard shad biomass must be reduced below $10 \mathrm{~g} / \mathrm{m}^{3}$ $(<200 \mathrm{~kg} / \mathrm{ha}$, on the basis of tank surface area) to achieve a significant reduction in phytoplankton biomass. This biomass of gizzard shad is lower than the typical biomass of gizzard shad in lakes and reservoirs (Aggus et al. 1979). Due to high fecundity and growth of gizzard shad (causing them to quickly reach a size refuge), the critical issue becomes whether a reduction in gizzard shad biomass below $10 \mathrm{~g} / \mathrm{m}^{3}$ can be achieved and maintained for more than one season to ensure a lasting reduction in phytoplankton biomass without having a detrimental effect on piscivorous game fish.

\section{Acknowledgments}

We are grateful for the assistance of D. Cross, M. Edwards, B. Farquhar, J. Hambrook, E. Lewis, and J. D. Smith and the suggestions of two anonymous referees. Research was supported by funds from ORSTOM action 2CA301 to X.L., NSF grant BSR-8906653 to R.W.D. and J.D.S., NSF grant BSR-9107173 to R.A.S , and the OSU Aquatic Ecology Laboratory.

\section{References}

Aggus, L. R., D. C. Carver, L. L. Olmsted, L. L. Rider, and G. E. SUMMERS. 1979. Evaluation of standing crops of fishes in Crooked Creek Bay, Barkley Lake, Kentucky. Proc. Annu. Conf. Southeast. Assoc. Fish Wildl. Agencies 33: 710-722.

ALI, A. B., AND D. R. BAYNE. 1987. Food related problems in bluegill populations of West Point Reservoir. Proc. Annu. Conf. Southeast. Assoc. Fish Wildl. Agencies 39: 207-216.

APHA (American Purlic Health Association). 1985. Standard methods for examination of water and wastewater. 16th ed. American Public Health Association, Washington, DC.

BOGDAN, K. G., AND J. J. GilBeRT. 1984. Body size and food size in freshwater zooplankton. Proc. Natl. Acad. Sci. USA 81: 6427-6431.

Braband, Å., B. A. FaAFEng, AND J. P. M. Nilssen. 1990. Relative importance of phosphorus supply to phytoplankton production: fish excretion versus external loading. Can. J. Fish. Aquat. Sci. 47: 364-372.

CARLANDER, K. D. 1977. Handbook of freshwater fishery biology. The Iowa State University Press, Ames, IA. 2 volumes. 739 and 423 p.

CARPENTER, S. R., J. F. KITCHELL, AND J. R. HODGSON. 1985. Cascading trophic interactions and lake productivity. BioScience 35: 634-639.

Carpenter, S. R., J. F. Kitchell, J. R. Hodgson, P. A. Cochran, J. J. Elser, M. M. ElSER, D. M. LODGE, D. KRETCHMER, X. He, AND C. N. VON ENDE. 1987. Regulation of lake primary productivity by food web structure. Ecology 68: 1863-1876.

COOPER, E. L., C. C. WAGNER, AND E. KRANTTZ. 1971. Bluegills dominate the production in mixed populations of fishes. Ecology 52: 280-290.

D'EliA, C. F., P. A. STEUDLER, AND N. CORWIN. 1977. Determination of total nitrogen in aqueous samples using persulfate digestion. Limnol. Oceanogr. 22: 760-764.

DeVRIEs, D. R., AND R. A. STEIN. 1990. Manipulating shad to enhance sport fisheries in North America: an assessment. N. Am. J. Fish. Manage. 10: 209-223.

DRenNeR, R. W., F. DE NoYelles JR., AND D. KeTtLe. 1982. Selective impact of filter-feeding gizzard shad on zooplankton community structure. Limnol. Oceanogr. 27: 965-968.

Drenner, R. W., K. D. Hambright, G. L. Vinyard, M. Gophen, and U. POLLINGHER. 1987. Experimental study of size-selective phytoplankton grazing by a filter-feeding cichlid and the cichlid's effects on plankton community structure. Limnol. Oceanogr. 32: 1138-1144.

DRENNER, R. W., AND S. R. MCCOMAS. 1980. The roles of zooplankton escape ability and fish size selectivity in the selective feeding and impact of planktivorous fish, p. 587-593. In W. C. Kerfoot [ed.] Evolution and ecology of zooplankton communities. University Press of New England, Hanover, NH.

DRENNER, R. W., AND J. D. SMITH. 1991. Biomass-dependent effects of mosquitofish on zooplankton, chlorophyll and the size distribution of particulate phosphorus. Verh. Int. Verein. Limnol. 24: 2382-2386.

DrenNer, R. W., J. D. Smith, J. R. Mummert, and H. F. Lancaster. 1989. Response of a eutrophic pond community to separate and combined effects of N:P supply and planktivorous fish: a mesocosm experiment. Hydrobiologia 208: 161-167.
Drenner, R. W., S. T. Threlkeld, AND M. D. MCCRAKEN. 1986. Experimental analysis of the direct and indirect effects of an omnivorous filterfeeding clupeid on plankton community structure. Can. J. Fish. Aquat. Sci. 43: 1935-1945.

GilberT, J. J. 1985. Competition between rotifers and Daphnia. Ecology 66: $1943-1950$.

GILBERT, J. J., AND R. S. STEMBERGER. 1985. Control of Keratella populations by interference competition from Daphnia. Limnol. Oceanogr. 30: 180188.

GRAN, G.. 1952. Determination of the equivalence point in potentiometric titrations. Part II. Analyst 77: 661-671.

HAmbright, K. D., R. J. Trebatoski, R. W. Drenner, and D. KetTle. 1986. Experimental study of the impacts of bluegill (Lepomis macrochirus) and largemouth bass (Micropterus salmoides) on pond community structure. Can. J. Fish. Aquat. Sci. 43: 1171-1176.

HILL, K. R. 1983. Comparison of fish standing stocks in small lakes with and without gizzard shad, p. 44-57. In D. Bonneau and G. Radonski [ed.] Proceedings of small lakes management workshop: pros and cons of shad. Iowa Conservation Commission, Des Moines, IA.

JANSSEN, J. 1976. Feeding modes and prey size selection in the alewife (Alosa pseudoharengus). J. Fish. Res. Board Can. 33: 1972-1975.

JENKINS, R. M. 1967. The influence of some environmental factors on standing crop and harvest of fishes in U.S. reservoirs, p. 298-321. In Reservoir Fisheries Resources Symposia, University of Georgia, Athens, GA. Southern Division, American Fisheries Society, Bethesda, MD.

KaJAK, Z., I. SPODNIEWSKA, AND R. J. WisniEWSKI. 1977. Studies on food selectivity of silver carp, Hypophthalmichthys molitrix (Val.). Ekol. Pol. 25: 227-239.

KIRK, J. P., AND W. D. DAVIES. 1987. Competitive influences of gizzard shad on largemouth bass and bluegill in small impoundments. Proc. Annu. Conf. Southeast. Assoc. Fish Wildl. Agencies 39: 116-124.

LAZZARO, X. 1987. A review of planktivorous fishes: their evolution, feeding behaviors, selectivities, and impacts. Hydrobiologia 146: 97-167.

MAZumder, A., D. J. MCQueEN, W. D. TAYLoR, AND D. R. S. LeAN. 1988. Effects of fertilization and planktivorous fish (yellow perch) predation on size distribution of particulate phosphorus and assimilated phosphate: large enclosure experiments. Limnol. Oceanogr. 33: 421-430.

MCQueen, D. J., M. R. S. Johannes, N. R. Lafontaine, A. S. Young, E. LONGBOTHAM, AND D. R. S. LEAN. 1990. Effects of planktivore abundance on chlorophyll- $a$ and secchi depth, p. 337-341. In R. D. Gulati, E. H. R. R. Lammens, M.-L. Meijer, and E. van Donk [ed.] Biomanipulation - tool for water management. Hydrobiologia 200/201. Kluwer Academic Publishers, Dordrecht, The Netherlands.

MCQUEEN, D. J., AND J. R. POST. 1985. Effects of planktivorous fish on zooplankton, phytoplankton and water chemistry, p. 35-42. In Lake and Reservoir Management, Proceedings of the Fourth Annual Conference, NALMS, October 1984, McAfee, NJ.

MCQUEEN, D. J., J. R. POST, AND E. L. Mills. 1986. Trophic relationships in freshwater pelagic ecosystems. Can. J. Fish. Aquat. Sci. 43: 1571-1581.

MENZEL, D. W., AND N. CORWIN. 1965. The measurement of total phosphorus in seawater based on the liberation of organically bound fractions by persulfate oxidation. Limnol. Oceanogr. 10: 280-282.

MiRANDA, L. E. 1983. Average ichthyomasses in Texas large impoundments. Annu. Proc. Tex. Chap. Am. Fish. Soc. 6: 58-67.

MUMmerT, J. R., AND R. W. DRENNER. 1986. Effect of fish size on the filtering efficiency and selective particle ingestion of a filter-feeding clupeid. Trans. Am. Fish. Soc. 115: 522-528.

NAKAShima, B. S., ANB W. C. LEGGETT. 1980. The role of fishes in the regulation of phosphorus availability in lakes. Can. J. Fish. Aquat. Sci. 37: 1540-1549.

NEL, W. E. 1984. Regulation of rotifer densities by crustacean zooplankton in an oligotrophic mountain lake in British Columbia. Oecologia 61: 175181

NOBLE, R. L. 1981. Management of forage fishes in impoundments of the southern United States. Trans. Am. Fish. Soc. 110: 738-750.

NORTHCOTE, T. G. 1988. Fish in the structure and function of freshwater ecosystems: a "top-down" view. Can. J. Fish. Aquat. Sci. 45: 361-379.

PARKIN, T. B., AND T. D. BROCK. 1980. Photosynthetic bacterial production in lakes: the effects of light intensity. Limnol. Oceanogr. 25: 711-718.

RUNGE, J. A., AND M. K. OHMAN. 1982. Size fractionation of phytoplankton as an estimate of food available to herbivores. Limnol. Oceanogr. 27: 570576.

SCHOONOVER, R., AND W. H. THOMPSON. 1954. A post-impoundment study of the fisheries resources of Fall Reservoir, Kansas. Trans. Kans. Acad. Sci. 57: $172-179$.

SHAPIRO, J. 1990. Biomanipulation: the next phase - making it stable, p. 1327. In R. D. Gulati, E. H. R. R. Lammens, M.-L. Meijer, and E. van 
Donke [ed.] Biomanipulation - tool for water management. Hydrobiologia 200/201. Kluwer Academic Publishers, Dordrecht, The Netherlands.

ShapiRo, J., V. LAMARRA, AND M. LyNCh. 1975. Biomanipulation: an ecosystem approach to lake restoration. Limnol. Res. Cent. Univ. Minn. 143: $1-32$.

SHAPIRO, J., AND D. I. WRIGHT. 1984. Lake restoration by lake manipulation: Round Lake, Minnesota, the first two years. Freshwater Biol. 14: 371383.

STOCKNER, J. G., M. E. KLUT, AND W. P. COChlan. 1990. Leaky filters: a warning to aquatic ecologists. Can. J. Fish. Aquat. Sci. 47: 16-23.

THRELKELD, S. T. 1987. Experimental evaluation of trophic-cascade and nutrient-mediated effects of planktivorous fish on plankton community structure, p. 161-173. In W. C. Kerfoot and A. Sih [ed.] Predation: direct and indirect impacts on aquatic communities. University Press of New England, Hanover, NH.

1988. Planktivory and planktivore biomass effects on zooplankton, phytoplankton, and the trophic cascade. Limnol. Oceanogr. 33: 1364 1377.

VANNI, M. J. 1986. Competition in zooplankton communities: suppression of small species by Daphnia pulex. Limnol. Oceanogr. 31: 1039-1056.

1987a. Effects of nutrients and zooplankton size on the structure of a phytoplankton community. Ecology $68: 624-635$.

$1987 \mathrm{~b}$. Effects of food availability and fish predation on a zooplankton community. Ecol. Monogr. 57: 61-88.
Vanni, M. J., C. Luecke, J. F. Kitchell, Y. Allen, J. Temte, and J. J. MAGNUSON. 1990. Effects on lower trophic levels of massive fish mortality. Nature (Lond.) 344: 333-335.

VANNI, M. J., AND J. TEMTE. 1990. Seasonal patterns of grazing and nutrient limitation of phytoplankton in an eutrophic lake. Limnol. Oceanogr. 35: 697-709.

VAN Veldhoven, P. P., AND G. P. MANNAERTS. 1987. Inorganic and organic phosphate measurements in the nanomolar range. Anal. Biochem. 161: 45-48.

VIJVERBERG, J., AND W. L. T. VAN DENSEN. 1984. The role of the fish in the foodweb of Tjeukemeer, The Netherlands. Verh. Int. Ver. Limnol. 22: 891-896.

WERNER, E. E. 1977. Species packing and niche complementarity in three sunfishes. Am. Nat. 111: 553-578.

WeTZEL, R. G., AND G. E. LiKENS. 1979. Limnological analyses. Saunders, Philadelphia, PA. 357 p.

WILKINSON, L. 1989. SYSTAT: the system for satistical analysis. SYSTAT Inc., Evanston, IL. 822 p.

WILliamson, C. E., AND J. J. GLLBERT. 1980. Variation among zooplankton predators: the potential of Asplanchna, Mesocyclops, and Cyclops to attack, capture, and eat various rotifer prey. Am. Soc. Limnol. Oceanogr. Spec. Symp. 3: 509-517.

WooD, L. W. 1985. Chloroform-methanol extraction of chlorophyll $a$. Can. J. Fish. Aquat. Sci. 42: 38-43. 